\title{
Management of Palmo-Plantar Psoriasis by Classical Shodhan and Shaman Chikitsa- A Case Report
}

\author{
Case Report
}

\section{Anagha S Hirapure ${ }^{*}$, Saurabh Deshmukh², Trupti Thakre ${ }^{3}$}

\author{
1. UG Scholar, 2. HOD \& Associate Professor, Department of Kayachikitsa, \\ 3. Assistant Professor, Department of Kaumarbhritya, \\ Mahatma Gandhi Ayurved College Hospital and Research Centre Salod (H) Wardha.
}

\begin{abstract}
Background: Palmo-plantar psoriasis in a non-inflammatory skin condition in which it is capable to produce functional disability. It is the type of psoriasis which occurs in palms and soles together with features like scaling, erythema and itching, pustules cracked \& pain, and is limited. Palmo-plantar is the disease which does not have a specific line of treatment, but can be assessed and treated with classical line of Ayurvedic management. This Palmoplantar not only affects physically but also disturbs the mental health of patient In Ayurveda all the skin diseases are described under single topic; Kushtha (Skin disorders). As Palmo-Plantar psoriasis is compared with Vipadika Kshudra Kushta (cracked bilateral soles \& palms) in Ayurveda, the predominant Dosha's (fundamental bodily bioelements) are Vata (governs movement of body \& mind) \& Kapha (controls immune system) in which Vaman Karma (Emesis) is useful. Aim: To evaluate the role of Ayurveda treatment modalities in Vipadika Kshudra Kushta. Materials \& Methods: A case report of 56 year old male patient suffering from scaling of both palms and soles with severe pain since 16 years is presented in this article where the patient got satisfactory relief by adopting Shodhan Karma (purification treatment) followed by Shaman Chikitsa (pacifying treatment) with dietary and behavioral lifestyle modification. The symptoms were reduced by Vaman procedure. Result: Patient got about $80 \%$ relief after the treatment by which one can say that the palmo-plantar psoriasis can be treated by Ayurveda Medicine.
\end{abstract}

Key Words: Kushtharoga, Palmo-plantra psoriasis, Shaman, Shodhan, Vaman, Vipadika.

\section{Introduction}

Palmoplantar psoriasis is an Autoimmune condition which flares up with exposure to the triggering factors. It is a type of skin disease which affects the both palms and soles. It is a condition which occur at any age but mostly seen between 20-60 yrs. of age group. Psoriasis is a non-contagious, chronic inflammatory condition which is characterized by red, scaly silvery plaques (1). It is also linked with the other health conditions like arthritis, irritable bowel syndrome. The name of psoriasis differs according to the site of appearance, as it appears in both palms and sole together known as Palmo- plantar psoriasis. It is characterized by appearance of hyperkeratosis, and pustules with erythema (2), scaling commonly in the central portion of palms and soles. A Palmoplantar pustule begins with small pin-sized eruption (3) in hands and soles \& pain while walking (4) (5). The condition is chronic and can produce significant functional disability which can cause impairment in quality of life and due to its recurrent nature; there is no

* Corresponding Author:

Anagha S. Hirapure

Scholar,

Mahatma Gandhi Ayurveda College,

Hospital \& Research Centre, Salod (H),

Sawangi (Meghe), Wardha (MH), India.

Email Id: anaghahirapure29@gmail.com specific treatment modality. In Ayurveda, the disease cause due to lifestyle changes in diet, stressful schedule and unsuitable/incompatible conditions suppression of natural urges, Etc. (6) According to Acharya Charak, it has been stated as all types of Kushtha is Tridoshaja (7) which vitiate the Twak (skin), Rakta (blood), Mamsa (muscles), Ambu (plasma) this all together cause the Kushtha (7) (8). According to Ayurveda palmo-plantar psoriasis can be related with the Vipadika Kshudra Kushta, characterized by Pani-Padasputan (cracks in soles and palms) associated with Tivravedana (severe pain on sites). It is predominant in Vata and Kapha Dosha's (9)

And it can be treated by Shodhana \& Shaman which can resist the reoccurrence of disease (10). The report deals with a case of Palmo-plantar psoriasis came for Ayurvedic treatment in term as of Shodhan Chikitsa followed by Shaman Karma. The informed written consent was obtained from the patient for the publication of present case report.

\section{Aims and objectives}

Aim

- To evaluate the efficacy of classical Vaman Karma with Shaman Chikitsa in the management of palmoplantar psoriasis.

\section{Objective}

- To Study the disease Vipadika - Kshudra Kushtha and Palmo-plantar psoriasis from available Ayurvedic and contemporary medical literatures. 
Anagha S. Hirapure et.al., Management of Palmo-Plantar Psoriasis by Classical Shodhan and Shaman Chikitsa-A Case Report

- To study the effect of Vaman Karma with Shaman Chikitsa in management of Palmo-plantar psoriasis.

\section{Materials and Methods}

According to Acharya, Kushtha is one of the indication for Vaman Karma (11). The line of treatment given to the patient was according to the treatment principle given in the classical text as Vamana karma (12), as per the prominence of Dosha the treatment mentioned- in Vataj and Kaphaj type of Kushtha is intake of Ghruta and Vaman (emesis) respectively. As Vipadika is the Vataj-Kaphaj Dosha predominant, the line of treatment can be given as Vaman karrma. Ayurveda has described the Palmo-plantar psoriasis under the Kushtharoga, which is managed by Vaman or Virechan followed by Shaman Chikitsa (13).

\section{Case Report}

A 56 year old male patient came to care on (14.01.2019) with the complaints of itching, cracked soles and palms, scaling in both palms and soles since 16 year (2003). The patient also has been suffering from constipation, stress, and pain during walking due to cracks on both soles. The patches on both palms and soles were gradually progressive and the onset was in subtle way. The patient has a history of constipation on \& off from 6-7 years. The patient was diagnosed to have Palmo-plantar psoriasis; He took allopathic treatment and got temporary relief and reappearance of symptoms. The patient has history of Hypertension since 10years. On examination, Dry, Scaly, Cracked skins were observed in bilateral soles and palms and local tenderness was present. Vyasan (Habits): Smoking.

\section{Past History}

The patient has the history of itching over both palms and soles, pain on sites along with cracks in bilateral soles and palms, took homeopathy treatment like Anti-fungal medicaments, creams, steroids for about 4 years got partial relief. He suffered the same complaints recurrently from 12 years, later the appearance of local tenderness became severe due to which he came for Ayurveda treatment.

\section{General Examination \\ Asthavidha Pariksha}

Table No. 1 - Asthavidha Pariksha

\begin{tabular}{|l|l|}
\hline Sthan & Lakshan \\
\hline Nadi (pulse) & 78/min (Mandagati) \\
\hline Mala (feces) & Vibhandha (Constipation) \\
\hline Mutra (urine) & Samyak (Normal) \\
\hline Jivha (tongue) & Niram (Non-coated) \\
\hline $\begin{array}{l}\text { Shabda } \\
\text { (speech) }\end{array}$ & $\begin{array}{l}\text { Spashta } \text { (Clear transitive } \\
\text { verb) }\end{array}$ \\
$\begin{array}{l}\text { Sparsha } \\
\text { (touch) }\end{array}$ & Anushnasheeta (Afebrile) \\
\hline Drik (eye) & Normal (No pallor/icterus) \\
\hline Akriti (shape) & Madhyam (Medium) \\
\hline
\end{tabular}

\section{Vital Data}

After examine the Ashtavidha (Table No.1)as per Ayurvedic perspective it is also important to measure vitals before the procedure. The pulse rate of the patient was $80 / \mathrm{min}$, while blood pressure in systole and diastole was $110 / 90 \mathrm{mmHg}$. The respiratory rate of the patient was $18 / \mathrm{min}$.

\section{Skin Examination}

- Inspection

- Size Shape- Scaling in both palms and soles

- Color- White Silvery scales

- Uniformity- Generalized plaques with Cracked

- Thickness- More than $0.5 \mathrm{~cm}$ in diameter

- Lesions- Plaques

- Palpation

- Moisture- Dryness, no sweating

- Temperature- warmth of the skin

- Texture- Roughness

- Mobility and turgor- reduced

\section{Differential Diagnosis}

Palmo- Plantar Psoriasis, Tenia Pedis, Palmoplantar Keratoderma

\section{Final Diagnosis}

Palmo-plantar Psoriasis

\section{Shodhan Chikitsa}

According to Koshta (nature of digestive tract) of patient i.e. Krura Koshta, predominant Dosha, and the condition of the disease Vaman Karma was planned. The patient was instructed about the Snehapan (Internal administration of Sneha Dravya), Swedana (steam therapy), dietary regimen, \& procedure of Shodhan.

According to the Acharya Vaghbhat, the person of Krura Koshta is contraindicated for Vaman Karma. (14). But during the period of Snehapana in Purvakarma it was observed that, the constipation of the patient was relieved, and the Vaman was planned instead of Virechan because according to Acharya, Vaman is best considered treatment for Kaphaj predominant Vyadhis. Vaman is priorly done before Virechan because if Kapha is eliminated by Vaman Karma then Virechan can be done easily but if the Virechan is planned before Vaman it will cause increase in Kapha Dosha and covers the Agni due to which Virechan is not possibly done.

The medicaments used for Vaman Karma as,

1.Deepan-Pachan (Appetizer \& Digestive) Dravya Agnitundivati,

2.Vamanopagadravya-Milk, Yashtimadhuphanta,

3.Vamakdravya - Madanphalachurna.

The procedure is divided in three parts Purva, Pradhan \& Paschat Karma (procedure before, at time, after the Vaman respectively).

\section{- Purva karma}

It has been believed in Ayurveda, every disease is originated from Koshtha to Shakha (bodily elements i.e. Saptadhatu), i.e. due to imbalance of Agni (digestive fire), the Dosha's become imbalance and though spread 
all over the Shakha and cause the disease. The Purvakarma plays an important part in bringing back the Dosha's from Shakha to Koshtha so as to eliminate.

- The patient was advised to administrate Agnitundi Vati $250 \mathrm{mg}$ twice a day with lukewarm water, before meal and to continue the same for 3 days ( $1{ }^{\text {st }}$ to $3^{\text {rd }}$ day).

- After 3 days, the patient was given Abhyantar Snehapana of Mahatiktaghruta for 7 days ( $4^{\text {th }}-10^{\text {th }}$ day). Started dosage with $30 \mathrm{ml}$ (2 -tablespoon) (Table No.2) with lukewarm water in morning on empty stomach.

- After the completion of Snehapan, the patient was observed for Sneha Siddhi Lakshana's (adequate oleation symptoms) as mentioned in classics such as Agni Dipti (increased digestive fire), Vatanuloman (movement of air in downward direction/ proper expulsion of flatulence), Shaithilya (lassitude) etc.

- As the Lakshana's appeared, the patient was given rest on $11^{\text {th }}$ day followed by Bahya Snehana and Swedan Karma, on rest day and on Vaman day i.e. $9^{\text {th }}$ and $11^{\text {th }}$ day (day of Vaman).

- Abhyanga (external oleation/massage) (Bahya Snehan) was done with Dashmula Taila, and Nadisweda with Dashmula Kwatha.

Table No. 2- Dose of Snehapan for 7 days

\begin{tabular}{|c|c|}
\hline Day & Dose \\
\hline Day 1 & $30 \mathrm{ml}$ \\
\hline Day 2 & $50 \mathrm{ml}$ \\
\hline Day 3 & $70 \mathrm{ml}$ \\
\hline Day 4 & $90 \mathrm{ml}$ \\
\hline Day 5 & $110 \mathrm{ml}$ \\
\hline Day 6 & $130 \mathrm{ml}$ \\
\hline Day 7 & $150 \mathrm{ml}$ \\
\hline
\end{tabular}

\section{- Pradhan Karma} at $7 \mathrm{am}$.

The Vaman Karma is performed in the morning

- On the day of Vaman, after the proper Abhyanga and Nadi Sweda and observation of symptoms of previous digested food, and proper sleep, the patient was advised to sit comfortably on chair.

- The vitals examinations were done.

- Intake of milk till stomach full was given.

- Administration of Madanphala Pippali Vamak Dravya with Vamanopaga Kwath of Yashtimadhu Phanta was given and observed for Samyak Siddhi
Lakshans (adequate Vaman procedure symptoms) such as sweating, discomfort in stomach and nausea.

- The patient was supported by massage over spine, and abdominal muscles to move upward for free evacuation.

- The Samyak Lakshanas (adequate procedure symptoms) were observed such as onset of Vega, feeling of lightness, absence of discomfort, sense of weakness.

- The Vegas (actual urge of vomitus) and Upavegas (nearer to urge of vomitus) and Antiki Dosha (End substance of vomitus) were observed.

\section{- Paschat karma}

- After the completion of Vaman Karma the patient was advised to take rest in a room avoidance of direct exposure of air, sound and not to sleep.

- The vitals were examined.

- The patient was given Dhumapana (medicated smoke).

- At the end the patient was asked to follow Samsarjan karma for 7 days. Starting from the day of Vaman. Along with behavioral changes patient is allowed to take Peya, Vilepi, Yavagu as a diet regimen.

\section{Observations}

- Vega-7 Vega

- Upvega-9 Upavega

- Antiki Dosha - Pitta Dosha

- Complications - No any complications

The patient's Vaman Karma resulted in Avara Shuddhi of Dosha which reduced the symptoms of previously aggravated Dosha.

\section{- Shaman Karma}

Acharya Charak has mentioned the role play of Panchakarma procedure by saying that the disease is treated by Shodhan does not reoccur but the diseases treated by Shaman may reoccur after the course of time (15) If the Shaman Dravya are administered after the proper Shodhan, it gives the additional effect and relief by removing the adherent Dosha in Strotas and helps to eradicate the diseases completely. While consultation to the patient, it was discussed regarding both Shaman and Shodhan Chikitsa.

After the Shodhan Karma, when Samsarjan Karma is completed, the patient was advised for Shaman Chikitsa (Table 3,4,5,6).

Table 3-Administration of medicine with their dose, duration, route and Anupan

\begin{tabular}{|l|l|l|l|l|l|} 
Sr. No & \multicolumn{1}{|c|}{ Drugs } & \multicolumn{1}{|c|}{ Dose \& Anupan } & \multicolumn{1}{|c|}{ Time } & \multicolumn{1}{c|}{ Rouration } \\
\hline 1 & Gandhak Rasayan & 2 tablets of 250mg & Twice a day & Oral & 30 days \\
\hline 2 & Atrisor cream & q.s & Thrice a day & Local Application & 30 days \\
\hline 3 & S-kin powder & With gomutra & Before bath & Local Application & 30 days \\
\hline 4 & 777 Oil & q.s & At night & Local Application & 30 days \\
\hline
\end{tabular}


Anagha S. Hirapure et.al., Management of Palmo-Plantar Psoriasis by Classical Shodhan and Shaman Chikitsa-A Case Report

\section{mode of Action}

\begin{tabular}{|l|l|l|} 
Ingredients & $\begin{array}{l}\text { Latin Nmae } \\
\text { Terminalia } \\
\text { chebula Retz }\end{array}$ & $\begin{array}{l}\text { Anti-pyretic, Anti- } \\
\text { helminthic }\end{array}$ \\
\hline $\begin{array}{l}\text { Shuddha } \\
\text { Gandhak }\end{array}$ & $\begin{array}{l}\text { Purified } \\
\text { Sulphur }\end{array}$ & $\begin{array}{l}\text { Anti-bacterial, Anti- } \\
\text { viral, Anti-microbial, } \\
\text { Anti-pruritics }\end{array}$ \\
\hline Guduchi & $\begin{array}{l}\text { Tinospora } \\
\text { cordifolia }\end{array}$ & $\begin{array}{l}\text { Anti-allergic, Anti- } \\
\text { pyretic, Anti-leprotic }\end{array}$ \\
\hline Amla & $\begin{array}{l}\text { Phyllanthus } \\
\text { emblica L. }\end{array}$ & $\begin{array}{l}\text { Anti-bacterial, Anti- } \\
\text { viral }\end{array}$ \\
\hline Bibhitaki & $\begin{array}{l}\text { Terminalia } \\
\text { bellerica L. }\end{array}$ & $\begin{array}{l}\text { Anti-allergic, Immune } \\
\text { booster }\end{array}$
\end{tabular}

Atrisor cream

\section{Table No 5 - Ingredients of Atrisor Cream with mode of action}

\begin{tabular}{|c|c|c|}
\hline Ingredients & Latin name & Actions \\
\hline Jivanti & $\begin{array}{l}\text { Leptadenia } \\
\text { reticulata }\end{array}$ & Anti-inflammatory \\
\hline Manjistha & Rubia cordifolia & $\begin{array}{l}\text { Anti-helminthics, } \\
\text { Anti-pyretics }\end{array}$ \\
\hline Haridra & Curcuma longa & $\begin{array}{l}\text { Anti-pyretic, Anti- } \\
\text { helminthic }\end{array}$ \\
\hline Streekutaja & $\begin{array}{l}\text { Wrightia } \\
\text { tinctoria (Roxb.) }\end{array}$ & Anti-fungal \\
\hline Kera taila & Cocos nucifera & $\begin{array}{l}\text { Anti-bacterial, } \\
\text { Anti-inflammatory }\end{array}$ \\
\hline $\begin{array}{l}\text { Tuvaraka } \\
\text { taila }\end{array}$ & $\begin{array}{l}\text { Hydnocarpus } \\
\text { wightiana }\end{array}$ & Anti-inflammatory \\
\hline
\end{tabular}

777 oil

Table No 6- Ingredients of 777 oil with their actions

\begin{tabular}{|l|l|l|} 
Ingredients & \multicolumn{1}{|c|}{ Latin name } & \multicolumn{1}{c}{ Actions } \\
Coconut oil & $\begin{array}{l}\text { Cocos } \\
\text { Nucifera }\end{array}$ & $\begin{array}{l}\text { Anti-bacterial, Anti- } \\
\text { inflammatory }\end{array}$ \\
\hline Swetakutaja & $\begin{array}{l}\text { Wrightia } \\
\text { Tinctoria }\end{array}$ & Anti-fungal \\
\hline
\end{tabular}

\section{Results}

After the Avara Shudhi of the patient by Vamanadi Shodhan Karma, followed by Shaman Chikitsa, the symptoms like pain soles and palm, cracked soles and palm, silvery scaly appearance of the disease were reduced. The patient got satisfactory relief from the older diseased complaints. (Table 7) (Fig. 1).

Table No. 7- Difference is appearance of Symptoms according to treatment.

\begin{tabular}{|l|l|l|l|}
\hline $\begin{array}{l}\text { Sr. } \\
\text { No }\end{array}$ & $\begin{array}{l}\text { Clinical Features } \\
\text { Before }\end{array}$ & $\begin{array}{c}\text { After } \\
\text { Treatment }\end{array}$ \\
\hline $\mathbf{1}$ & $\begin{array}{l}\text { Cracks in soles and } \\
\text { palms }\end{array}$ & +++ & + \\
\hline $\mathbf{2}$ & Local tenderness & +++ & + \\
\hline $\mathbf{3}$ & Scaly appearance & +++ & $\begin{array}{l}\text { No scaly } \\
\text { appearance }\end{array}$ \\
\hline $\mathbf{4}$ & Itching & +++ & No Itching \\
\hline $\mathbf{5}$ & $\begin{array}{l}\text { Skin } \\
\text { eruption(pustules) }\end{array}$ & +++ & + \\
\hline & & & \\
\hline
\end{tabular}

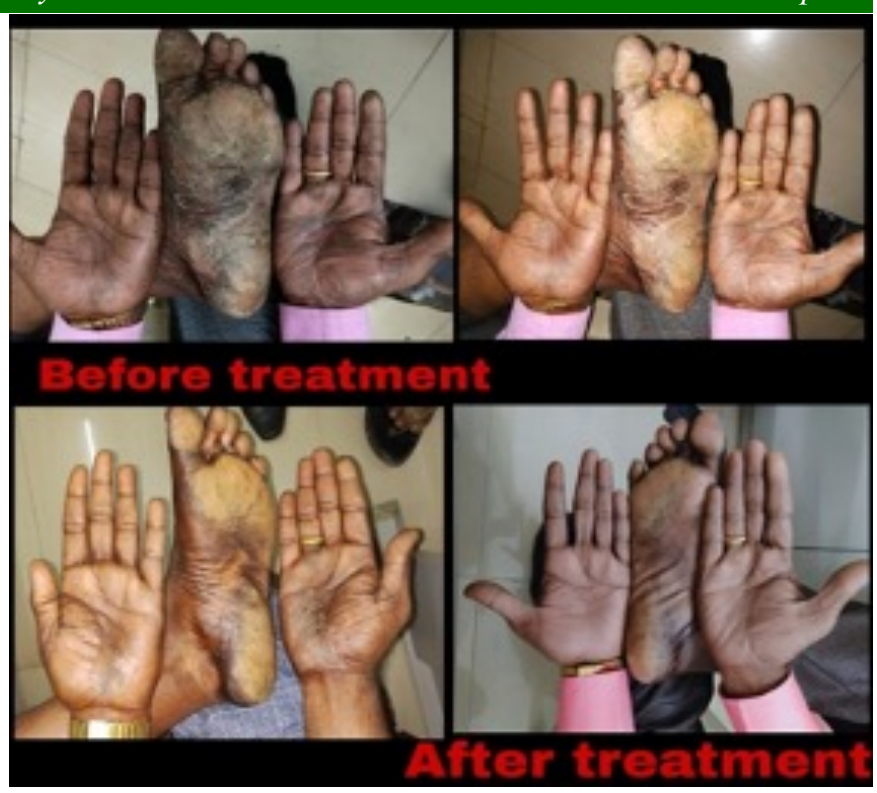

Fig. 1 - The picture depict the condition of patient having Palmo-plantar psoriasis before and after treatment.

\section{Discussion}

According to Ayurvedic literature, psoriasis can be correlated with Kushtha by having predominance of Vata, Pitta, Kapha and Rasa, Rakta, Mamsadhatu and skin as Upadhatu of Mamsadhatu. (16). In the present case study the patient was first treated with digestive and carminative (Deepen-Pachan) treatment by Agnitundi Vati having kuchla (nux-vomica seeds) as main ingredient. It is considered as best appetizer and has the digestive potency which digest the Aam (Undigested Food) from koshta (colon) further which relieve the vibandha (constipation)and simultaneously increase the digestive fire. By stimulating the digestive juices it improves the bowel movement. Its Later transferred to Abhyang and Nadi Sweda to aggravate the Dosha and liquefy the Dosha in the site of presence and bring back to Koshtha which after eliminated following Shodhan Karma i.e. Vaman. Other literatures such as Sharangdhara Samhita, Bhaisajya Ratnavali Adhikaran and Ashtang Hridaya, Acharya has stated that Mahatikta Ghruta has the properties like Tikta rasa, Ushna virya, and Ghruta as a base which is capable of maintenance of Rasa Dhatu and hence indirectly helps to treat the Kushtha. As Kushtha is the disease which occurs due to vitiation of Tridoshas the Gandhak rasayan was used in Shaman Chikitsa which is beneficial for maintaining the normal status of Raktadhatu as well as maintain the normalcy in perspiration in order to remove pitta and Kapha from body hence this drug is beneficial for skin disorders. The palmo-plantar psoriasis is correlated with Vipadika Kshudra Kushtha, in which Vata and Kapha dosha are predominance. So, the treatment was given to eliminate the impaired dosha from Koshtha by Vaman Karma. After the proper Shodhan Karma, in Shaman Chikitsa cream was advised for local application as a necessity mentioned by Acharya (17). So, the Atrisor cream was advised to use as topical application. It is an herbal anti-psoriatic topical cream which gives quick relief from the symptoms like dryness, itching and signs 
of inflammation. By its emollient action it helps in bringing back the normal texture and complexion of skin. At the end he was also advised to use 777oil for local application as it has the soothing effect and act as a moisturizer to skin by its nutritive ingredients such as coconut oil. In the condition like psoriasis, the damaged cells produce rapidly and form the thickened skin itching, dryness and scaly appearance is produced over the site. By the action of the contents present in the oil it softens the area and makes it soft by reducing dryness. It acts as a demulcent. All this Shaman Chikitsa treats the psoriasis by reducing its signs and symptoms.

\section{Conclusion}

In the present study almost satisfactory result were seen in signs and symptoms of such autoimmune disease like palmo-plantar psoriasis by the Shodhan Karma and Shaman chikitsa. As the disease mentioned under the Kushtharoga, originated by imbalance of Tridosha the vamam procedure was advised to remove the impaired dosha from koshta which is followed by shaman chikitsa.. Large sample studies would render a better result of the in such complicated disease. Both the procedures and drugs were well tolerated by the patient and no adverse drug reaction was reported. Hence it can be concluded that shodhan karma along with topical application of cream can be effectively used in palmo-plantar psoriasis.

\section{References}

1. Agnivesha, Charak, Dridhabala, Charak Samhita, Chikitsa Sthana, Chapter 7,Vidhishonitadhyay Vidyotini Hindi Commentary by Dr. BrahmanandaTripathi, Chowkhamba Bharati Academy 2009.p.no.305

2. Agnivesha, Charak, Dridhabala, Charak Samhita, NidanSthana, Chapter 14, shloka 3, Vidhishonitadhyay Vidyotini Hindi Commentary by Dr. BrahmanandaTripathi, Chowkhamba Bharati Academy 2010.p.no.369.

3. Srikantha Murthy K.R, Ashtanga Hradayama, NidanSthana, 14th chapter. Varanasi: Choukhamba Krishnadas Academy .p.no.139.

4. Agnivesha, Charak, Dridhabala, Charak Samhita, Chikitsa Sthana, chapter 7, Vidhishonitadhyay Vidyotini Hindi Commentary by Dr. BrahmanandaTripathi, ChowkhambaBharati Academy 2017.p.no.325.

5. Agnivesha, Charak, Dridhabala, Charak Samhita, Chikitsa Sthana, chapter 7, Vidhishonitadhyay Vidyotini Hindi Commentary by Dr. BrahmanandaTripathi, ChowkhambaBharati Academy 2009.

6. Agnivesha, Charak, Dridhabala, Charak Samhita, Chikitsa Sthana, chapter 7, Shloka 4-8, Vidhishonitadhyay Vidyotini Hindi Commentary by Dr. BrahmanandaTripathi, ChowkhambaBharati Academy 2009.

7. Agnivesha, Charak, Dridhabala, Charak Samhita, Chikitsa Sthana, chapter 7, Shloka 9-10, Vidhishonitadhyay Vidyotini Hindi Commentary by Dr. Brahmananda Tripathi, Chowkhamba Bharati Academy 2009.

8. Agnivesha, Charak, Dridhabala, Charak Samhita, Chikitsa Sthana, chapter 14, Vidhishonitadhyay Vidyotini Hindi Commentary by Dr. Brahmananda Tripathi, Chowkhamba Bharati Academy 2010. 530p.

9. Agnivesha, Charak, Dridhabala, Charak Samhita, Chikitsa Sthana, chapter 7,shloka 27-30 Vidhishonitadhyay Vidyotini Hindi Commentary by Dr. Brahmananda Tripathi, Chowkhamba Bharati Academy 2009.

10. Agnivesha, Charak, Dridhabala, Charak Samhita, Chikitsa Sthana, chapter 7, shloka 22-29 Vidhishonitadhyay Vidyotini Hindi Commentary by Dr. Brahmananda Tripathi, Chowkhamba Bharati Academy 2013.

11. Agnivesha, Charak, Dridhabala, Charak Samhita, siddhiSthana, chapter 2, shloka 10 Vidhishonitadhyay Vidyotini Hindi Commentary by Dr. Brahmananda Tripathi, Chowkhamba Bharati Academy 2009.

12. Agnivesha, Charak, Dridhabala, Charak Samhita, Chikitsa Sthana, chapter 7, shloka 39 Vidhishonitadhyay Vidyotini Hindi Commentary by Dr. Brahmananda Tripathi, Chowkhamba Bharati Academy 2009.

13. Agnivesha, Charak, Dridhabala, Charak Samhita, Chikitsa Sthana, chapter 7, shloka 30-31 Vidhishonitadhyay Vidyotini Hindi Commentary by Dr. Brahmananda Tripathi, Chowkhamba Bharati Academy 2009.p39-42.

14. Agnivesha, Charak, Dridhabala, Charak Samhita, Sutra Sthana, chapter 18, shloka 1-2, 10-11 Vidhishonitadhyay Vidyotini Hindi Commentary by Dr. Brahmananda Tripathi, Chowkhamba Bharati Academy 2009.

15. Agnivesha, Charak, Dridhabala, Charak Samhita, chikitsaSthana, chapter 7, shloka 15-17, Vidhishonitadhyay Vidyotini Hindi Commentary by Dr. Brahmananda Tripathi, Chowkhamba Bharati Academy 2009.

16. Agnivesha, Charak, Dridhabala, Charak Samhita, chikitsaSthana, chapter 7, Vidhishonitadhyay Vidyotini Hindi Commentary by Dr. Brahmananda Tripathi, Chowkhamba Bharati Academy 2009.

17. Agnivesha, Charak, Dridhabala, Charak Samhita, chikitsaSthana, chapter 2, shloka 7 , Vidhishonitadhyay Vidyotini Hindi Commentary by Dr. Brahmananda Tripathi, Chowkhamba Bharati Academy 2009. 